\title{
Design of experiments to assess pre-treatment and co-digestion strategies that optimize biogas production from macroalgae Gracilaria vermiculophylla
}

\author{
J.V. Oliveira, M.M. Alves, J.C. Costa* \\ CEB - Centre of Biological Engineering, University of Minho, 4710-057 Braga, Portugal
}

\section{H I G H L I G H T S}

\section{- G. vermiculophylla was pre-treated} and co-digested with glycerol and sewage sludge.

- Washing and maceration caused a significant increase in the seaweed BMP.

- Thermochemical pre-treatments increased the algae solubilisation but not its BMP.

- Adding $2 \%$ of glycerol increased the BMP by $18 \%$ ( $\left.599 \pm 16 \mathrm{~L} \mathrm{CH}_{4} \mathrm{~kg}^{-1} \mathrm{VS}\right)$.

- Co-digestion of G. vermiculophylla with sewage sludge generated $605 \pm 4 \mathrm{~L} \mathrm{CH}_{4} \mathrm{~kg}^{-1}$ VS.

\section{A R T I C L E I N F O}

\section{Article history:}

Received 22 January 2014

Received in revised form 21 March 2014

Accepted 28 March 2014

Available online 8 April 2014

\section{Keywords:}

Algae

Gracilaria sp.

Glycerol

Pre-treatment

Sewage sludge
G R A P H I C A L A B S T R A C T

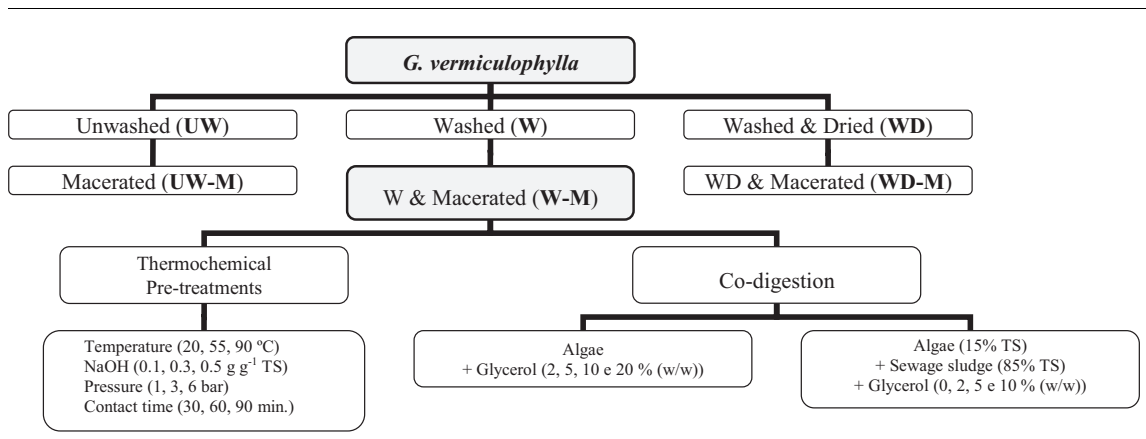

\begin{abstract}
A B S T R A C T
A design of experiments was applied to evaluate different strategies to enhance the methane yield of macroalgae Gracilaria vermiculophylla. Biochemical Methane Potential (BMP) of G. vermiculophylla after physical pre-treatment (washing and maceration) reached $481 \pm 9 \mathrm{~L} \mathrm{CH}_{4} \mathrm{~kg}^{-1} \mathrm{VS}$, corresponding to a methane yield of $79 \pm 2 \%$. No significant effects were achieved in the BMP after thermochemical pretreatment, although the seaweeds solubilisation increased up to $44 \%$. Co-digestion with glycerol or sewage sludge has proved to be effective for increasing the methane production. Addition of $2 \%$ glycerol $(\mathrm{w}: \mathrm{w})$ increased the BMP by $18 \%$, achieving almost complete methanation of the substrate $(96 \pm 3 \%)$. Co-digestion of seaweed and secondary sludge (15:85\%, TS/TS) increased the BMP by $25 \%\left(605 \pm 4 \mathrm{~L} \mathrm{CH}_{4}\right.$ $\mathrm{kg}^{-1} \mathrm{VS}$ ) compared to the seaweed individual digestion.
\end{abstract}

() 2014 Elsevier Ltd. All rights reserved.

\section{Introduction}

In the quest for new biofuels, anaerobic digestion of macroalgae should be seen as a promising source of bioenergy in the future. Algae have several advantages over other energy crops, including

\footnotetext{
* Corresponding author. Address: Universidade do Minho, Departamento de Engenharia Biológica, Campus de Gualtar, 4710-057 Braga, Portugal. Tel.: +351 253 604 400; fax: +351253604 429 .

E-mail address: carloscosta@deb.uminho.pt (J.C. Costa).
}

high growth yields and rates, the capacity to capture $\mathrm{CO}_{2}$, and do not compete with food crops for arable land and irrigation water. The anaerobic digestion is a multifunctional process that allows nutrient recycling, production of biogas, a sustainable bioenergy carrier, and reduction of waste volume (Appels et al., 2011; Mottet et al., 2010). Macroalgae (or seaweeds) have high concentration of carbohydrates, making it a good substrate for biogas production through anaerobic digestion processes (Costa et al., 2013).

Gracilaria vermiculophylla is a species of red seaweed, originally from Japan, and recently found in European waters as an invasive 
species (Villanueva et al., 2010). In Portugal, G. vermiculophylla populations can be found in Ria de Aveiro (Sousa et al., 2010), a geographical area with strong anthropogenic influence, such as cities, tourism, fishing activities, aquaculture and agriculture, resulting in high concentration of nitrogen and consequently in eutrophication of the marine environment (Abreu et al., 2011). The anaerobic digestion of the macroalgae will concomitantly reduce environmental problems and produce a renewable energy. The theoretical methane production potential of Gracilaria is $400 \mathrm{~L} \mathrm{CH}_{4} \mathrm{~kg}^{-1}$ VS (Bird et al., 1990). However, the Biochemical Methane Potential (BMP) of Gracilaria spp. experimentally determined was $182 \pm 23 \mathrm{~L} \mathrm{CH}_{4} \mathrm{~kg}^{-1}$ VS, i.e. less than $50 \%$ of that value (Costa et al., 2012b), giving rise to opportunities for improving substrate utilization and methane production, including pre-treatment and co-digestion strategies. The overall anaerobic digestion process of macroalgae alone and in co-digestion with sewage sludge was limited by the hydrolysis (Costa et al., 2012b). Physical, chemical and thermochemical pre-treatments might be suitable to increase the hydrolysis rate as demonstrated for other types of wastes (Costa et al., 2012a).

On the other hand, the co-digestion of two or more complementary substrates may induce a synergetic effect on their biodegradability, causing an increase in the methane yield and production rate. In the case of seaweeds, their high protein content requires the co-digestion with a co-substrate with high concentration of carbon and deficit in nitrogen (Costa et al., 2013). Glycerol is a by-product of biodiesel manufacturing industry and, nowadays, its growing production exceeds the commercial demand (Johnson and Taconi, 2007; Siles et al., 2010). Options for the biological conversion of glycerol into added value products are becoming increasingly important, including anaerobic co-digestion with several substrates (Ma et al., 2008; Fountoulakis et al., 2010; Regueiro et al., 2012). Glycerol, being an easily acidifying compound, its amendment as co-substrate should be carefully evaluated in order to prevent process imbalance. In general, addition of glycerol up to $6 \%$ can significantly boost the methane production, but higher concentrations can be inhibitory (Fountoulakis et al., 2010; Amon et al., 2006).

Co-digestion with sewage sludge is another process that can improve the methane production from seaweeds. It was already demonstrated that the co-digestion of Ulva sp. (15\% TS) with sewage sludge ( $85 \%$ TS) is feasible at a rate of methane production $26 \%$ higher than sewage sludge alone, without decreasing the overall biodegradability of the substrate (42-45\% methane yield) (Costa et al., 2012b).

The aim of this study was to assess the effect of physical and thermochemical pre-treatment on the methane yield and methane production rate of $G$. vermiculophylla. Co-digestion with glycerol and sewage sludge was also evaluated as alternatives to improve the energetic valorisation of G. vermiculophylla.

\section{Methods}

\subsection{Inoculum and substrate}

Anaerobic granular sludge from a wastewater treatment plant, located in the Centre of Portugal, which treats brewery's wastewater, was used as inoculum in all biodegradability assays. The sludge samples contained $38.9 \pm 2.6 \mathrm{~g} \mathrm{~L}^{-1}$ of volatile solids (VS). The specific methanogenic activity (SMA) in the presence of acetate (30 mM) was $214 \pm 17 \mathrm{~mL} \mathrm{CH}_{4}$ @STP $\mathrm{g}^{-1} \mathrm{VS} \mathrm{d}^{-1}$, and in the presence of $\mathrm{H}_{2} / \mathrm{CO}_{2}(80 / 20 \mathrm{v} / \mathrm{v}, 1 \mathrm{~atm})$ was $389 \pm 16 \mathrm{~mL} \mathrm{CH}_{4} @$ @TP $\mathrm{g}^{-1} \mathrm{VS} \mathrm{d}^{-1}$. SMA was determined according to described in Costa et al., (2012b).

G. vermiculophylla was collected in Ria de Aveiro (Portugal), in March 2012, and used as the main substrate in this study. Each sample was characterised in terms of solids, chemical oxygen demand (COD), nitrogen and lipids. In co-digestion assays two substrates were used: glycerol and sewage sludge. Glycerol was produced in December 2010 from vegetable oils and stored at $4{ }^{\circ} \mathrm{C}$ since then. Sewage sludge was collected in June 2012 from the secondary treatment of Frossos Wastewater Treatment Plant (WWTP) (Braga, Portugal). Both co-substrates were characterised in terms of solids and COD.

\subsection{Biodegradability assays}

Anaerobic biodegradability tests were used to assess the BMP and the methane production rate $(k)$ from the seaweed $G$. vermiculophylla according to the scheme shown in Fig. 1.

\subsubsection{Physical pre-treatments}

G. vermiculophylla was divided in three fractions: (i) without any pre-treatment (unwashed, UW); (ii) washed with water to remove impurities (W); and, (iii) washed and dried at $37^{\circ} \mathrm{C}$ (WD). Afterwards, each sample was sub-divided in two samples, without or with maceration (UW-M, W-M, WD-M). During maceration the algae were cut to less than $0.5 \mathrm{~cm}$ and then crushed with a mortar. The biodegradability assays lasted approximately 28 days. The objective was to determine which of the applied physical pre-treatment (washing, drying and maceration) enables higher specific methane production and production rate. The other tests (after thermochemical pre-treatment and co-digestion assays) were performed using the sample with the highest specific methane production.

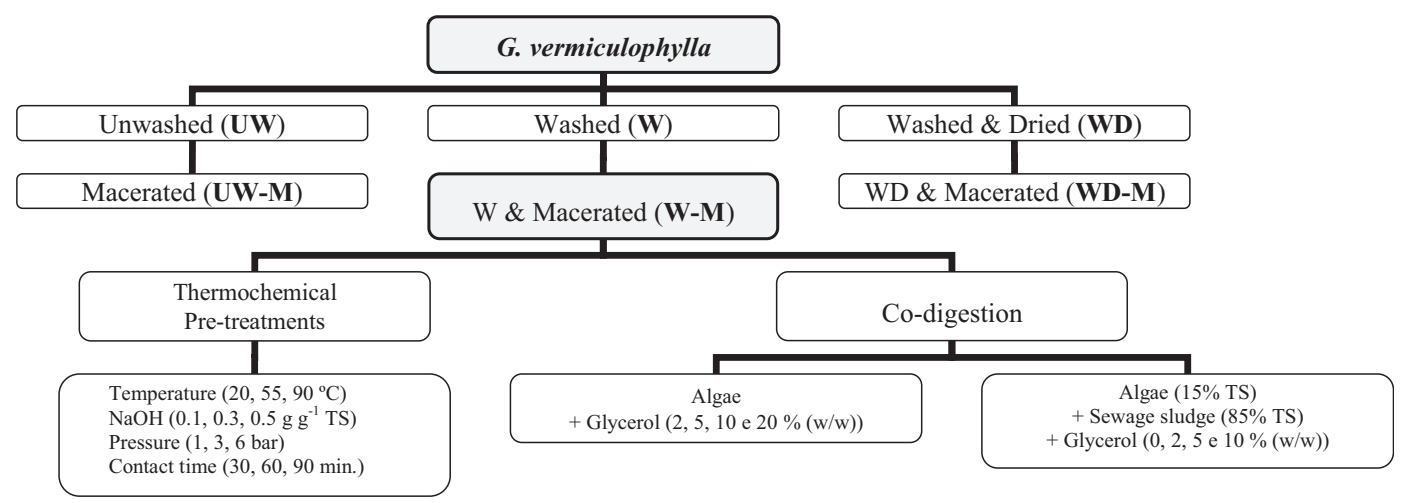

Fig. 1. Sequential degradation tests performed with G. vermiculophylla, glycerol and sewage sludge. 
Table 1

Factors used in the CCF experimental design and respective levels.

\begin{tabular}{lllll}
\hline Factors & Unity & Level -1 & Level 0 & Level +1 \\
\hline Contact time $(\mathrm{tc})$ & $\min$ & 30 & 60 & 90 \\
NaOH concentration $\left(C_{\mathrm{NaOH}}\right)$ & $\mathrm{g}_{\mathrm{NaOH}} \mathrm{g}_{\text {algae }}^{-1}$ & 0.1 & 0.3 & 0.5 \\
Temperature $(T)$ & ${ }^{\circ} \mathrm{C}$ & 20 & 55 & 90 \\
Pressure $(P)$ & bar & 1.0 & 3.5 & 6.0 \\
\hline
\end{tabular}

\subsubsection{Thermochemical pre-treatments}

Planning of the thermochemical pre-treatments was performed using a surface response methodology design of experiments. In this way is possible to objectively evaluate the effect on response variables and respective interactions of changing diverse process variables (factors). It uses combinations of levels, allowing the definition of a surface response to describe the interactions between the factors. A set of experiments following a design of experiments maximizes the amount of information obtained with the minimum number of tests (NIST/SEMATECH, 2012). The response surface model Box-Wilson Central Composite Design - Face Centered (CCF) was chosen to perform the analysis. In this model, each operating point is at a distance of \pm 1 of the factorial central point, thus requiring three levels of each factor (NIST/SEMATECH, 2012).

The factorial design was used to determine the optimal conditions that cause higher solubilisation of $G$. vermiculophylla. Four factors, (i) temperature $(T)$, (ii) pressure $(P)$, (iii) contact time (ct), and (iv) concentration of alkali $\left(C_{\mathrm{NaOH}}\right)$, were studied at three levels (Table 1). It is a design based on two-level factorial designs, containing a central point (CP) and $2 \alpha$ extra points ( $\alpha$ is the number of variables in study, i.e. 4) to verify the influence of one factor keeping the remaining constant, or at the central level (0). The number of experiments can be determined by Eq. (1) (Rosa et al., 2007):

$n \cdot{ }^{\circ}$ experiences $=2^{\alpha}+2 \alpha+\mathrm{CP}$

The experimental assays were performed in closed vials with $50 \mathrm{~g} \mathrm{~L}^{-1}$ of total solids (TS) of G. vermiculophylla washed and macerated. Assays with overpressure ( 3.5 and 6.0 bar) were performed in a pressure column equipped with a pressure transducer and a regulatory valve. Column pressurisation was made through the injection of $\mathrm{N}_{2}$. Experiments were performed randomly. Soluble COD concentration was determined before and after thermochemical treatment. The Design-Expert ${ }^{\circledR}$ software (Stat-Ease Inc., Minneapolis, USA) was used to determine the array analysis and statistical processing of results. Significance was set to $p<0.05$.

After carrying out the thermochemical pre-treatment four samples were selected to perform anaerobic biodegradability assays, which represent different percentages of solubilisation. Total initial $\operatorname{COD}\left(\mathrm{COD}_{\mathrm{t}}\right)$ was kept constant in all assays and the soluble COD after pre-treatment $\left(\mathrm{COD}_{\mathrm{s}}\right)$ was $75,59,28$ and $7 \mathrm{mg}_{\text {seaweed }}^{-1}$ The $\mathrm{pH}$ was neutralized with hydrochloric acid $(8 \mathrm{M})$ and the tests lasted around 24 days.

\subsubsection{Co-digestion}

In the first set of experiments, different co-digestion assays with G. vermiculophylla and glycerol were performed during 60 days. Glycerol was added in different percentages, i.e. 0\% (control), $2 \%, 5 \%, 10 \%$ and $20 \%$ (extra mass of glycerol relative to the mass of seaweed). Then, a second set of experiments was performed using a mixture of G. vermiculophylla (15\% TS) and sewage sludge ( $85 \%$ TS). Then, different percentages of glycerol $(0 \%, 2 \%, 5 \%$ and $10 \%)$ were added to this mixture. These tests lasted around 42 days.

\subsubsection{Experimental procedure}

The biodegradability assays were performed according to the guidelines defined in Angelidaki et al. (2009), with 50\% (v/v) of inoculum, at $37^{\circ} \mathrm{C}$, and with an inoculum to substrate ratio of $4 \mathrm{~g} \mathrm{VS}_{\text {inoculum }} \mathrm{g}^{-1} \mathrm{VS}_{\text {substrate. }}$. All the assays were performed in triplicate and a blank (without substrate) was used to discount the residual substrate present in the inoculum.

Methane accumulated in the vials' headspace was measured by gas chromatography using a gas tight syringe to sample $500 \mu \mathrm{L}$. Methane production was corrected for standard temperature and pressure (STP) conditions $\left(0{ }^{\circ} \mathrm{C}\right.$ and $\left.1 \mathrm{~atm}\right)$. BMP was determined by unit of VS of substrate added to the assays, as previously described by Costa et al. (2012a). Relative methane production (MP) was defined as the amount of methane produced during the assays in relation to the theoretical BMP (i.e. $350 \mathrm{~L} \mathrm{CH}_{4} \mathrm{~kg}^{-1}$ COD) (Costa et al., 2012a). Hydrolysis was evaluated considering the percentage of solubilisation (PS), which is the percentage of the initial COD added to the vials that was solubilised during the anaerobic biodegradability assay (Costa et al., 2012a). The percentage of solubilisation during the thermochemical pre-treatment $\left(\mathrm{PS}_{\mathrm{pt}}\right)$ was calculated as the percentage of the initial COD added to the test that was solubilised during the pre-treatment (Costa et al., 2012a).

\subsection{Analytical methods}

Ammonium $\left(\mathrm{N}-\mathrm{NH}_{4}^{+}\right)$was determined by the Nessler method (APHA et al., 1998). Total Kjeldahl nitrogen (TKN), TS and VS were measured according to Standard Methods (APHA et al., 1998). Total and soluble COD were determined using standard kits (Hach Lange, Düsseldorf, Germany). Lipid content was extracted with diethyl ether in a Soxtec System. The oily waste was added to thimbles previously weighted and placed in the apparatus. The temperature of the circulating heating fluid was $90^{\circ} \mathrm{C}$. After extraction, the samples were dried and the weight was recorded (Official Methods of Analysis, 2007). The protein content was determined based on the TKN measurement using the correction factor 6.25 (Bruni et al., 2010; Lourenço et al., 2002; Msuya and Neori, 2008). Carbohydrates were estimated as the remaining fraction of volatile solids after the determination of protein and lipids (Alvarez et al., 2010).

Volatile Fatty Acids (VFAs) were determined by Jasco HPLC (Tokyo, Japan), using a Metacarb column maintained at $60{ }^{\circ} \mathrm{C}$ and with UV/VIS detection at $210 \mathrm{~nm}$. The mobile phase was sulfuric acid $(5 \mathrm{mM})$ fed at a rate of $0.6 \mathrm{~mL} \mathrm{~min}{ }^{-1}$. Crotonic acid was used as internal standard. Long chain fatty acids (LCFA) (lauric C12:0, myristic C14:0, palmitic C16:0, palmitoleic C16:1, stearic C18:0 and oleic C18:1 acids) analyses was done as described in Neves et al. (2009). The LCFA were analysed in the liquid and solid matrix since they were adsorbed/accumulated onto the solid matrix. Free fatty acids present in the samples were esterified with $\mathrm{HCl}$ :1-propanol and extracted with dichloromethane. Quantification was done with a gas chromatograph (GC) equipped with a flame ionization detector (FID). LCFA were separated using a CP-Sil 52 CB column with helium as the carrier gas fed at a rate of $1 \mathrm{~mL} \mathrm{~min}^{-1}$. Temperatures of the injector and detector were 220 and $250{ }^{\circ} \mathrm{C}$, respectively. The initial oven temperature was $50^{\circ} \mathrm{C}$, maintained for $2 \mathrm{~min}$, followed by a $10^{\circ} \mathrm{C} \mathrm{min}-1$ ramp up to $225^{\circ} \mathrm{C}$ and finally isothermal conditions were maintained for $10 \mathrm{~min}$.

Methane content of the biogas was analysed with a GC (Chrompack 9000), as described in Costa et al. (2012a). The GC was equipped with a FID $(2 \mathrm{~m} \times 2 \mathrm{~mm})$ and Carbowax $20 \mathrm{M}(80-120$ mesh) column. Nitrogen was used as carrier gas $\left(30 \mathrm{~mL} \mathrm{~min}^{-1}\right)$. The detector, injector, and oven temperatures were 35,110 , and $220^{\circ} \mathrm{C}$, respectively. 


\subsection{Statistical analysis}

An exponential model (Eq. (2)) was used to describe the progress of cumulative methane production obtained from the batch experiments.

$M(t)=P\left(1-e^{-k t}\right)$

Where $M(t)$ is the cumulative methane production ( $\mathrm{mg}$ COD- $\mathrm{CH}_{4}$ ), $P$ is the maximum methane production ( $\left.\mathrm{mg} \mathrm{COD}-\mathrm{CH}_{4}\right), k$ is the methane production rate constant $\left(\mathrm{d}^{-1}\right)$, and $t$ is the time $(\mathrm{d})$. Biodegradability results were compared after a significance statistical analysis by using a single factor analysis of variance (ANOVA). Statistical significance was established at $p<0.05$ level.

\section{Results and discussion}

\subsection{Substrates characterisation}

Characterisation of G. vermiculophylla, glycerol and sewage sludge is shown in Table 2 . Since the seaweed was directly captured in their natural environment, the presence of impurities and potentially toxic compounds to anaerobic digestion, such as high salinity, sand, small shellfish, etc., influence their characterisation. For example, sand and small molluscs shells have a strong influence on the solids content as observed by the VS of the unwashed sample. The small soluble COD concentration, only 3$10 \%$ of the total COD, suggests the need of a pre-treatment to increase the organic matter solubilisation. TKN from G. vermiculophylla is below those found in the literature, 6-8.7\% (Bird et al., 1990; Costa et al., 2012b), featuring COD:N ratios between 22 and 31:1. The sample of crude glycerol had 16\% (w/w) of LCFA, being linoleic acid (51\%), oleic acid (32\%), palmitic acid (11\%), and stearic acid (4\%).

\subsection{Anaerobic biodegradability after the physical pre-treatments}

The cumulative methane production from G. vermiculophylla after physical pre-treatment is shown in Fig. 2a, while the experimental results at the end of the assays are shown in Table 3. The macerated samples achieved higher methane yields compared with the respective unmacerated samples, approximately $10 \%$ for the washed and unwashed samples, and 5\% for washed and dried sample. Also, Briand and Morand (1997) found that the maceration of Ulva sp. caused an increase of $22 \%$ in the methane produced. Maceration increases the surface area making the substrate more accessible to the inoculum, facilitating a fast hydrolyses and providing higher biodegradation rates. Increases of $25-42 \%$ in the methane production rate constants were observed in the macer- ated samples (Table 3 ). The higher specific methane production was achieved with the washed and macerated (W-M) sample, i.e. $481 \pm 9 \mathrm{~L} \mathrm{CH}_{4} \mathrm{~kg}^{-1} \mathrm{VS}$. It was found that the samples maceration increased the specific methane production by $8-15 \%$. The washing process increased the methane production over $40 \%$, confirming the presence of inhibitory compounds in the raw samples, for instance, excess salt may have caused partial inhibition of the methanogenic activity.

The drying process did not cause an increase in the macroalgae BMP, i.e. the sample WD-M produced $349 \pm 44 \mathrm{~L} \mathrm{CH}_{4} \mathrm{~kg}^{-1} \mathrm{VS}$. This behaviour has been previously observed in the biodegradability of the macroalgae Ulva lactuca (Bruhn et al., 2011). One disadvantage of use seaweeds as energy crops for biogas production, compared with terrestrial energy crops, is the high water content. $G$. vermiculophylla washed sample had less than $14 \%$ TS (Table 2). Drying is an effective method, although expensive due to the energy consumption in the process, to decrease the water content and to improve the seaweeds storage and stability. Though the specific methane production was smaller after drying the G. vermiculophylla, it was possible to verify a methane production boost in terms of methane yield per mass of seaweed. Indeed, the WD-M sample achieved $240 \pm 2 \mathrm{~L} \mathrm{CH}_{4} \mathrm{~kg}^{-1}$ seaweed, while the W-M sample produced only $45 \pm 1 \mathrm{~L} \mathrm{CH}_{4} \mathrm{~kg}^{-1}$ seaweed. Therefore, drying the sample may be the only effective way to digest seaweeds in a continuous reactor, to increase the organic loading rate.

Regarding the samples solubilisation, it was observed behaviour similar to the methane production. Indeed, the PS reached $87 \pm 2 \%$ in the $\mathrm{W}$-M sample and $79 \pm 10 \%$ in the WD-M sample. The presence of impurities, such as sand and small rocks, makes the unwashed sample more difficult to solubilise (Table 3).

Once more, the maceration increased the values of PM and PS by $7-15 \%$, compared with the respective fractions of unmacerated seaweed.

A significant increase in the specific methane production was observed, compared with the results presented in Costa et al. (2012b), where the PM and PS ranged from 38\% to 47\% and 43\% to $51 \%$, respectively. By comparing the two studies it is possible to highlight three differences that contributed for the different results: (i) the higher inoculum to substrate ratio (ISR); (ii) the different source/type and higher methanogenic activity of the inoculum; and, (iii) the sample pre-treatment. Indeed, the present study was performed with an ISR $=4 \mathrm{~g} \mathrm{VS}_{\text {inoculum }} \mathrm{g}^{-1} \mathrm{VS}_{\text {substrate }}$, whereas in the previous study by Costa et al. (2012b) the ISR was lower (0.14-0.70 $\left.\mathrm{g} \mathrm{VS}_{\text {inoculum }} \mathrm{g}^{-1} \mathrm{VS}_{\text {substrate }}\right)$ limiting the biodegradability process. Contrary to the theoretically expected, the methane potential of a given substrate depends on the inoculum type used in the assays. The low SMA of the digested sludge used in the previous study also limited the PM and PS determined.

Table 2

Characterisation of the different samples of G. vermiculophylla, glycerol, and sewage sludge used in the anaerobic biodegradability assays.

\begin{tabular}{|c|c|c|c|c|c|c|}
\hline \multirow[t]{2}{*}{ Parameter } & & \multicolumn{3}{|c|}{ G. vermiculophylla } & \multirow[t]{2}{*}{ Glycerol } & \multirow[t]{2}{*}{ Sewage sludge } \\
\hline & & UW & W & WD & & \\
\hline TS & $\%$ & $21.5 \pm 1.9$ & $13.6 \pm 0.6$ & $91.7 \pm 1.7$ & $71.5 \pm 2.8$ & $16.7 \pm 0.2$ \\
\hline VS & $\%^{\mathrm{a}}$ & $47.7 \pm 6.5$ & $69.4 \pm 4.3$ & $70.0 \pm 2.8$ & $94.7 \pm 3.9$ & $83.8 \pm 0.8$ \\
\hline $\mathrm{COD}_{\mathrm{T}}$ & $\mathrm{g} \mathrm{g} \mathrm{gubstrate}^{-1}$ & $0.16 \pm 0.01$ & $0.16 \pm 0.01$ & $0.82 \pm 0.04$ & $1.44 \pm 0.02$ & $0.29 \pm 0.01$ \\
\hline CODs & $\mathrm{g} \mathrm{g} \mathrm{g}_{\text {substrate }}^{-1}$ & $0.011 \pm 0.000$ & $0.005 \pm 0.000$ & $0.086 \pm 0.001$ & $1.44 \pm 0.02$ & $0.052 \pm 0.000$ \\
\hline TKN & $\%^{\mathrm{a}}$ & $2.51 \pm 0.03$ & $4.75 \pm 0.92$ & $3.95 \pm 0.09$ & nd & nd \\
\hline Proteins & $\%^{\mathrm{a}}$ & $33.9 \pm 0.4$ & $42.9 \pm 8.3$ & $35.3 \pm 0.8$ & nd & nd \\
\hline Lipids & $\%$ & nd & $0.03 \pm 0.01$ & $0.24 \pm 0.09$ & nd & nd \\
\hline Carbohydrates & $\%^{\mathrm{a}}$ & nd & $26.5 \pm 9.3$ & $34.5 \pm 2.9$ & nd & nd \\
\hline
\end{tabular}

nd, not determined; UW, unwashed; W, washed; WD, washed and dried at $37^{\circ} \mathrm{C}$.

a Dry basis. 

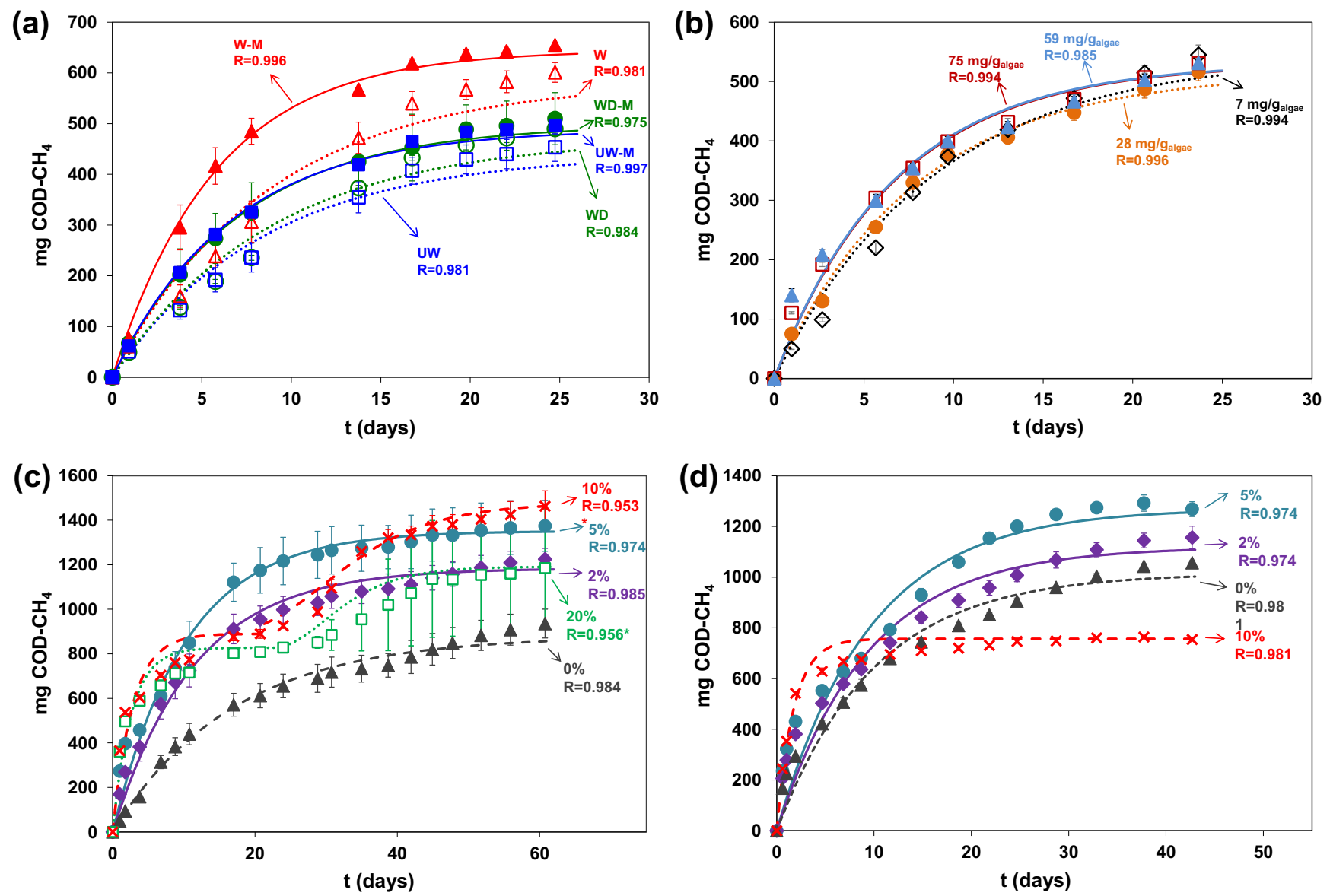

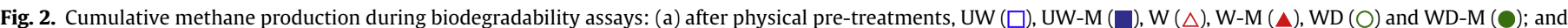

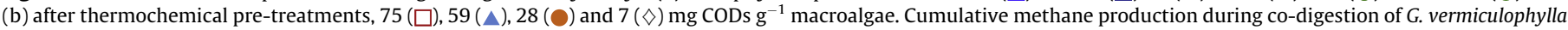

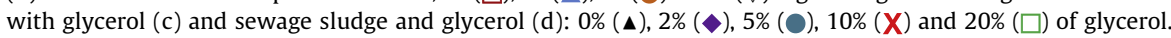

Table 3

Experimental results obtained at the end of the biodegradability assays with G. vermiculophylla samples after physical-pre-treatments.

\begin{tabular}{|c|c|c|c|c|c|c|c|}
\hline & & \multicolumn{6}{|c|}{ Gracilaria vermiculophylla } \\
\hline & & UW & UW-M & W & W-M & WD & WD-M \\
\hline BMP & $\mathrm{LCH}_{4} \mathrm{~kg}^{-1} \mathrm{VS}$ & $295 \pm 26$ & $338 \pm 6$ & $430 \pm 17$ & $481 \pm 9$ & $324 \pm 6$ & $349 \pm 44$ \\
\hline PM & $\%$ & $55 \pm 5$ & $63 \pm 1$ & $71 \pm 3$ & $79 \pm 2$ & $73 \pm 1$ & $78 \pm 10$ \\
\hline PS & $\%$ & $53 \pm 5$ & $61 \pm 1$ & $77 \pm 3$ & $87 \pm 2$ & $74 \pm 2$ & $79 \pm 10$ \\
\hline$k$ & $d^{-1}$ & $0.12 \pm 0.01$ & $0.15 \pm 0.01$ & $0.12 \pm 0.01$ & $0.17 \pm 0.01$ & $0.11 \pm 0.01$ & $0.14 \pm 0.02$ \\
\hline $\mathrm{pH}$ & & $7.43 \pm 0.02$ & $7.36 \pm 0.02$ & $7.32 \pm 0.02$ & $7.29 \pm 0.02$ & $7.40 \pm 0.01$ & $7.38 \pm 0.05$ \\
\hline CODs & $\mathrm{g} \mathrm{L}^{-1}$ & $0.62 \pm 0.08$ & $0.68 \pm 0.03$ & $1.17 \pm 0.07$ & $1.39 \pm 0.07$ & $1.11 \pm 0.10$ & $1.12 \pm 0.02$ \\
\hline VFA & $\mathrm{g} \mathrm{L}^{-1}$ & $0.27 \pm 0.07$ & $0.25 \pm 0.05$ & $0.20 \pm 0.09$ & $0.17 \pm 0.05$ & $0.28 \pm 0.11$ & $0.56 \pm 0.28$ \\
\hline $\mathrm{NH}_{4}^{+}-\mathrm{N}$ & $\mathrm{g} \mathrm{L}^{-1}$ & $1.48 \pm 0.22$ & $1.46 \pm 0.02$ & $1.71 \pm 0.04$ & $1.71 \pm 0.02$ & $1.75 \pm 0.21$ & $1.58 \pm 0.10$ \\
\hline
\end{tabular}

Note: The values obtained in the blanks $\left(121 \mathrm{mg} \mathrm{COD}-\mathrm{CH}_{4}\right)$ were subtracted in the data presented in the table.

The W-M sample achieved the best results, with a BMP 10-39\% higher than other samples, therefore in the subsequent biodegradability assays with thermochemical pre-treatment and co-digestion, it was used a washed and macerated sample of $G$. vermiculophylla, avoiding the energy needed to dry the seaweed.

3.3. Anaerobic biodegradability after the thermochemical pretreatments

\subsubsection{Pre-treatments}

The percentage of solubilisation during the pre-treatment $\left(\mathrm{PS}_{\mathrm{pt}}\right)$ ranged from $1.1 \%$ (conditions: $30 \mathrm{~min}, 0.1 \mathrm{~g} \mathrm{NaOH} \mathrm{g}^{-1} \mathrm{TS}, 20^{\circ} \mathrm{C}$ and 1 bar) and $44.3 \%$ (conditions: $30 \mathrm{~min}, 0.5 \mathrm{~g} \mathrm{NaOH} \mathrm{g}^{-1} \mathrm{TS}, 90^{\circ} \mathrm{C}$ and
6 bar) (Table 4). The results were analysed using a quadratic model and ANOVA aiming at determine the variables with the greatest influence on the sample solubilisation and the existence of significant interactions between the variables tested. Only three variables, $C_{\mathrm{NaOH}}(p=0.0006), T(p<0.0001)$ and $P(p=0.0001)$; and two interactions, $C_{\mathrm{NaOH}}$ vs. $T(p=0.0141)$ and $T$ vs. $P(p=0.0395)$ have a significant influence on the seaweeds solubility. It should be noted that lower $p$ values means greater relevance of the term to the model. It was found that the contact time had little influence on the algae solubilisation. Therefore, the model can be described by the following equation $(p<0.0001)$.

$\sqrt{\text { CODs }}=108.7+11.1 B+37.8 C+13.2 D+7.6 B C+6.1 C D$ 
Table 4

Operational conditions and soluble COD obtained during thermochemical pretreatments.

\begin{tabular}{|c|c|c|c|c|c|c|}
\hline Test & $\begin{array}{l}\mathrm{tc} \\
(\mathrm{min})\end{array}$ & $\begin{array}{l}C_{\mathrm{NaOH}} \\
\mathrm{g} \mathrm{g}^{-1}\end{array}$ & $\begin{array}{l}T \\
\left({ }^{\circ} \mathrm{C}\right)\end{array}$ & $\begin{array}{l}P \\
\text { (bar) }\end{array}$ & $\begin{array}{l}\text { CODs } \\
\mathrm{g} \mathrm{L}^{-1}\end{array}$ & $\begin{array}{l}\text { PSpt } \\
(\%)\end{array}$ \\
\hline$\underline{1}$ & 90 & 0.5 & 90 & 6 & 27.5 & 43.0 \\
\hline 2 & 90 & 0.5 & 90 & 1 & 18.5 & 28.0 \\
\hline 3 & 90 & 0.5 & 20 & 6 & 5.2 & 5.8 \\
\hline 4 & 90 & 0.5 & 20 & 1 & 3.3 & 2.6 \\
\hline 5 & 90 & 0.1 & 90 & 6 & 20.7 & 31.6 \\
\hline 6 & 90 & 0.1 & 90 & 1 & 10.3 & 14.3 \\
\hline 7 & 90 & 0.1 & 20 & 6 & 3.7 & 3.3 \\
\hline$\underline{8}$ & 90 & 0.1 & 20 & 1 & 2.3 & 1.0 \\
\hline 9 & 30 & 0.5 & 90 & 6 & 28.3 & 44.3 \\
\hline 10 & 30 & 0.5 & 90 & 1 & 16.5 & 24.6 \\
\hline 11 & 30 & 0.5 & 20 & 6 & 4.5 & 4.6 \\
\hline 12 & 30 & 0.5 & 20 & 1 & 2.8 & 1.8 \\
\hline 13 & 30 & 0.1 & 90 & 6 & 18.4 & 27.8 \\
\hline 14 & 30 & 0.1 & 90 & 1 & 6.5 & 7.9 \\
\hline 15 & 30 & 0.1 & 20 & 6 & 5.8 & 6.8 \\
\hline 16 & 30 & 0.1 & 20 & 1 & 2.4 & 1.1 \\
\hline 17 & 60 & 0.3 & 55 & 3.5 & 10.8 & 15.1 \\
\hline$\overline{18}$ & 90 & 0.3 & 55 & 3.5 & 13.1 & 19.0 \\
\hline 19 & 30 & 0.3 & 55 & 3.5 & 8.7 & 11.7 \\
\hline$\underline{20}$ & 60 & 0.5 & 55 & 3.5 & 21.5 & 33.0 \\
\hline 21 & 60 & 0.1 & 55 & 3.5 & 10.2 & 14.1 \\
\hline 22 & 60 & 0.3 & 90 & 3.5 & 26.6 & 41.5 \\
\hline 23 & 60 & 0.3 & 20 & 3.5 & 3.5 & 2.9 \\
\hline 24 & 60 & 0.3 & 55 & 6 & 10.9 & 15.3 \\
\hline 25 & 60 & 0.3 & 55 & 1 & 10.5 & 14.6 \\
\hline
\end{tabular}

Note: The samples underlined were selected to use in the biodegradability assays.

Where, $B, C$ and $D$ take values between -1 and 1 (Table 1 ). Eq. (3)shows that the maximum value of $\mathrm{COD}_{s}$ is reached with the significant parameters in its maximum value, i.e. $C_{\mathrm{NaOH}}=0.5 \mathrm{~g} \mathrm{~g}^{-1} \mathrm{TS}$, $T=90^{\circ} \mathrm{C}$ and $P=6$ bar.

The effect of the significant interactions, $B C$ and $C D$, on the soluble COD are graphically represented in Fig. 3. The figures express the influence of the represented variables in the solubilisation of organic matter, i.e. to higher values of temperature, pressure and concentration of $\mathrm{NaOH}$, corresponds higher CODs, in the interval studied. An important remark is that the increase in soluble COD obtained with $P \geqslant 4$ bar is almost negligible (Fig. 3b), meaning that significant energy savings can be attained operating at $<4$ bar. It is also clear that the parameter with higher influence in the seaweed solubilisation is the Temperature.

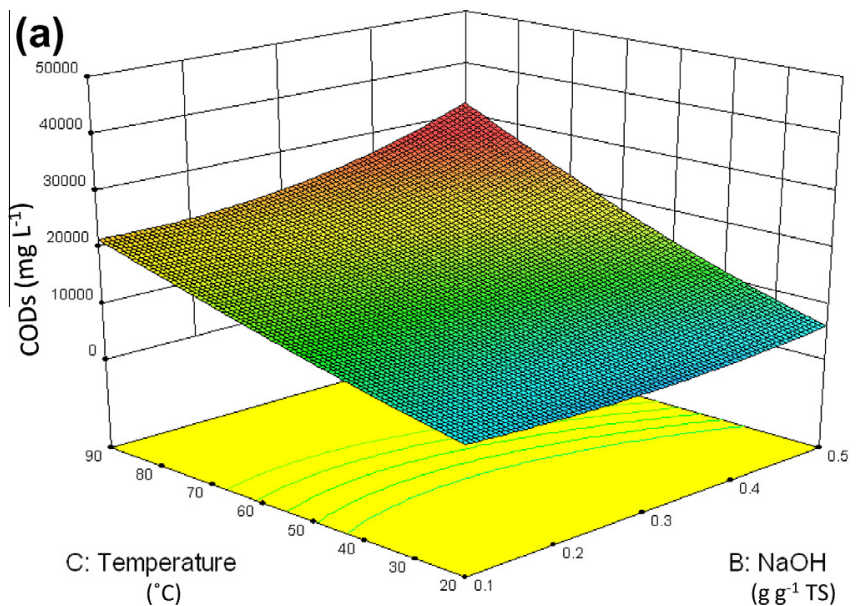

\subsubsection{Anaerobic biodegradability}

Four samples of pre-treated G. vermiculophylla (Table 4), with different initial soluble COD concentration (75, 59, 28 and $7 \mathrm{mg} \mathrm{CODs} \mathrm{g}^{-1}$ seaweed), were added to vials and the specific methane production was determined. The total COD was kept constant while the initial soluble COD varied. The cumulative methane production profiles are shown in Fig. $2 \mathrm{~b}$.

No significant effects were observed in the biodegradability results. In fact, the BMP ranged from $353-380 \mathrm{~L} \mathrm{CH}_{4} \mathrm{~kg}^{-1} \mathrm{VS}$, the PM from 58\% to 63\%, and the final solubilisation percentage (pretreatment + anaerobic digestion) from $82 \%$ to $87 \%$. The results show that the samples with low initial solubility were efficiently solubilised during the anaerobic digestion process, meaning that a prior maceration of the seaweed is more important than the thermochemical pre-treatment applied. However it should be noted the highest biodegradability constant rate $\left(0.15 \pm 0.02 \mathrm{~d}^{-1}\right)$ of the assay with higher initial CODs compared with the assay with lowest initial CODs $\left(0.11 \pm 0.02 \mathrm{~d}^{-1}\right)$. Therefore, the pre-treatment of the samples caused changes in the structure of the organic matter, which facilitated the initial production of methane. No inhibitions were found, the VFA varied between 0.22 and $0.34 \mathrm{~g} \mathrm{~L}^{-1}$ and the ammonium was between 0.96 and $1.03 \mathrm{~g} \mathrm{NH}_{4}^{+}-\mathrm{N} \mathrm{L}^{-1}$.

Thermochemical pre-treatments have associated high energetic and reagents costs. Considering this fact and the results obtained during the anaerobic biodegradability of the pre-treated seaweed, it seems that these pre-treatments should be avoided because no significant impact/increase in terms of methane production will be obtained.

\subsection{Co-digestion}

\subsubsection{G. vermiculophylla and glycerol}

The cumulative methane production obtained in the co-digestion assays with G. vermiculophylla and varying percentages of glycerol $(w / w)$ is presented in Fig. 2c. The absolute methane production increased with increasing percentages of glycerol, except in the assay with $20 \%$ glycerol, which was inhibited. The sample with $10 \%$ glycerol presented the highest methane production (1400 $\mathrm{mg} \mathrm{COD}-\mathrm{CH}_{4}$ ), but a latent stage between days 10 and 25 was observed. Indeed, in the assays with high glycerol concentrations (10\% and $20 \%$ ) although the faster initial production of methane, subsequent latent phases were observed, and ultimately the methanogenesis step was inhibited.

The results at the end of the co-digestion assays are shown in Table 5 . The highest specific methane production was obtained in

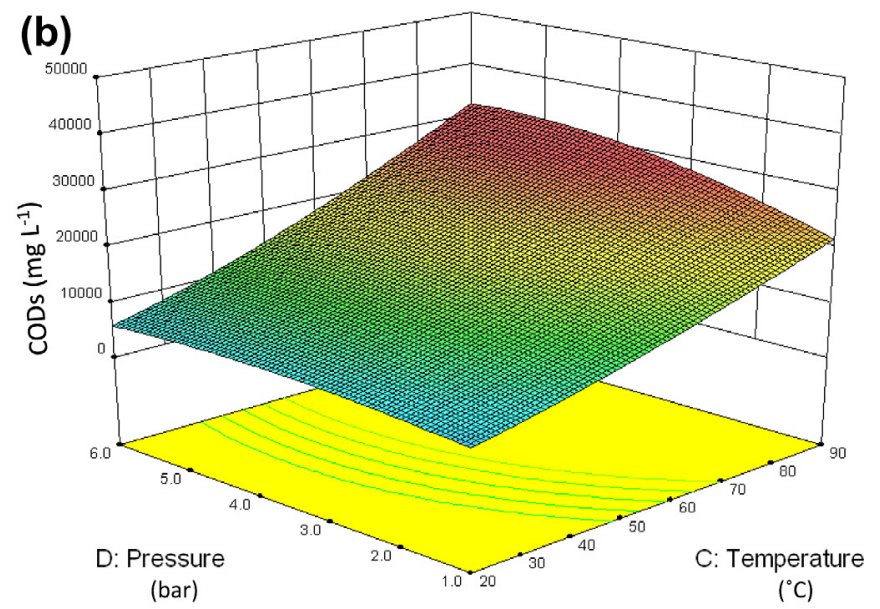

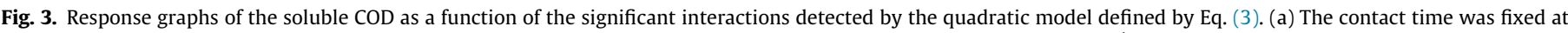
$65.5 \mathrm{~min}$ and the pressure at 5.62 bar. (b) The contact time was fixed at $65.5 \mathrm{~min}$ and the $\mathrm{NaOH}$ concentration at $0.5 \mathrm{~g} \mathrm{~g}^{-1} \mathrm{TS}$. 
Table 5

Experimental results obtained at the end of the co-digestion assays with G. vermiculophylla and glycerol.

\begin{tabular}{|c|c|c|c|c|c|c|}
\hline & & \multicolumn{5}{|l|}{ Glycerol (w/w) } \\
\hline & & $0 \%$ & $2 \%$ & $5 \%$ & $10 \%$ & $20 \%$ \\
\hline BMP & $\mathrm{LCH}_{4} \mathrm{~kg}^{-1} \mathrm{VS}$ & $506 \pm 43$ & $599 \pm 16$ & $581 \pm 50$ & $493 \pm 25$ & $275 \pm 72$ \\
\hline PM & $\%$ & $84 \pm 7$ & $96 \pm 3$ & $90 \pm 8$ & $74 \pm 4$ & $40 \pm 10$ \\
\hline PS & $\%$ & $105 \pm 8$ & $102 \pm 4$ & $87 \pm 2$ & $66 \pm 1$ & $36 \pm 1$ \\
\hline$k$ & $\mathrm{~d}^{-1}$ & $0.06 \pm 0.00$ & $0.09 \pm 0.0$ & $0.10 \pm 0.01$ & $0.36 \pm 0.01^{a}$ & $0.39 \pm 0.01^{\text {a }}$ \\
\hline $\mathrm{pH}$ & & $7.42 \pm 0.01$ & $7.45 \pm 0.03$ & $7.45 \pm 0.06$ & $7.49 \pm 0.06$ & $6.88 \pm 0.40$ \\
\hline CODs & $\mathrm{g} \mathrm{L}^{-1}$ & $1.28 \pm 0.21$ & $2.15 \pm 0.47$ & $5.11 \pm 2.01$ & $11.5 \pm 1.5$ & $26.7 \pm 2.5$ \\
\hline VFA & $\mathrm{g} \mathrm{L}^{-1}$ & $0.20 \pm 0.04$ & $0.32 \pm 0.24$ & $2.56 \pm 1.54$ & $4.72 \pm 1.75$ & $23.5 \pm 3.0$ \\
\hline LCFA & $\mathrm{g} \mathrm{L}^{-1}$ & $0.089 \pm 0.049$ & $0.078 \pm 0.030$ & $0.077 \pm 0.009$ & $0.34 \pm 0.04$ & $1.27 \pm 0.21$ \\
\hline $\mathrm{NH}_{4}^{+}-\mathrm{N}$ & $\mathrm{g} \mathrm{L}^{-1}$ & $2.11 \pm 0.23$ & $2.60 \pm 0.11$ & $3.24 \pm 0.22$ & $3.25 \pm 0.13$ & $3.16 \pm 0.37$ \\
\hline
\end{tabular}

Note: The values obtained in the blanks $\left(158 \mathrm{mg} \mathrm{COD}-\mathrm{CH}_{4}\right)$ were subtracted in the data presented in the table.

a Values determined by the exponential model using the data until day 24 (before the lag-phase).

Table 6

Experimental results obtained at the end of the co-digestion assays of G. vermiculophylla (15\% TS) and secondary sludge (85\% TS) with glycerol.

\begin{tabular}{|c|c|c|c|c|c|}
\hline & & \multicolumn{4}{|c|}{ Glycerol (w/w) } \\
\hline & & $0 \%$ & $2 \%$ & $5 \%$ & $10 \%$ \\
\hline BMP & $\mathrm{LCH}_{4} \mathrm{~kg}^{-1} \mathrm{VS}$ & $605 \pm 4$ & $611 \pm 15$ & $611 \pm 23$ & $276 \pm 5$ \\
\hline PM & $\%$ & $85 \pm 1$ & $86 \pm 2$ & $85 \pm 3$ & $38 \pm 1$ \\
\hline PS & $\%$ & $88 \pm 1$ & $79 \pm 2$ & $84 \pm 3$ & $71 \pm 0$ \\
\hline$k$ & $d^{-1}$ & $0.10 \pm 0.01$ & $0.11 \pm 0.01$ & $0.10 \pm 0.01$ & $0.58 \pm 0.03$ \\
\hline $\mathrm{pH}$ & & $7.40 \pm 0.01$ & $7.44 \pm 0.02$ & $7.45 \pm 0.05$ & $7.12 \pm 0.01$ \\
\hline CODs & $\mathrm{g} \mathrm{L}^{-1}$ & $1.08 \pm 0.07$ & $1.43 \pm 0.32$ & $6.42 \pm 2.56$ & $22.5 \pm 0.6$ \\
\hline VFA & $\mathrm{g} \mathrm{L}^{-1}$ & $0.55 \pm 0.11$ & $0.44 \pm 0.05$ & $3.28 \pm 0.47$ & $14.7 \pm 1.4$ \\
\hline LCFA & $\mathrm{g} \mathrm{L}^{-1}$ & $0.12 \pm 0.03$ & $0.11 \pm 0.02$ & $0.28 \pm 0.09$ & $3.71 \pm 1.97$ \\
\hline $\mathrm{NH}_{4}^{+}-\mathrm{N}$ & $\mathrm{g} \mathrm{L}^{-1}$ & $2.12 \pm 0.24$ & $2.12 \pm 0.33$ & $2.99 \pm 0.18$ & $3.37 \pm 0.15$ \\
\hline
\end{tabular}

Note: The values obtained in the blanks $\left(152 \mathrm{mg} \mathrm{COD}-\mathrm{CH}_{4}\right)$ were subtracted in the data presented in the table.

the assay with $2 \%$ glycerol ( $\left.599 \pm 16 \mathrm{~L} \mathrm{CH}_{4} \mathrm{~kg}^{-1} \mathrm{VS}\right)$. This value represents an increase of $18 \%$ in the specific methane production compared with the value obtained in the sole digestion of $G$. vermiculophylla, i.e. in the test with $0 \%$ glycerol. In this assay almost all available substrate was converted to methane as indicated by the PM of $96 \pm 3 \%$. Analysing the results is possible to verify that the inhibitory effect started with the addition of $5 \%$ glycerol. With increasing concentrations of glycerol the accumulation of metabolites and toxic compounds caused increasingly inhibition effects, as seen by the decreasing values of BMP and PM and by the high concentrations of VFA, LCFA and $\mathrm{NH}_{4}^{+}-\mathrm{N}$ (Table 5). Thus, special attention should be considered when adding glycerol as co-substrate because, although it can be a powerful way to improve the methane production, it can easily inhibit the anaerobic digestion process if secure thresholds are exceeded. For instance, the VFA reached $4.7 \pm 1.8$ and $23.5 \pm 3.0 \mathrm{~g} \mathrm{~L}^{-1}$ in the tests with $10 \%$ and $20 \%$ glycerol, respectively. These values are significantly higher than the $2 \mathrm{~g} \mathrm{~L}^{-1}$, suggested as the limit of tolerance of methanogens to VFA (Nkemka and Murto, 2010). Moreover, free ammonia concentration exceeded $110 \mathrm{mg} \mathrm{NH}_{3}-\mathrm{N} \mathrm{L}^{-1}$ in the assays with $5 \%$ and $10 \%$ glycerol. According to Hansen et al. (1998), inhibitory effects may be found with free ammonia concentration between 100 and $1100 \mathrm{mg} \mathrm{L}^{-1}$.

\subsubsection{G. vermiculophylla, sewage sludge and glycerol}

Anaerobic co-digestion assays were performed by using 15\% TS of seaweed and $85 \%$ TS of sewage sludge and increasing concentrations $(w / w)$ of glycerol. The seaweed to sludge ratio was optimized in a previous work of Costa et al. (2012b) and 15:85\% (TS:TS) was found to be the ratio with the maximum specific methane production and production rate. The cumulative production is shown in Fig. $2 d$, while the final experimental results are shown in Table 6 .
A significant increase in the specific methane production was observed with the co-digestion of seaweed and sewage sludge $\left(605 \pm 4 \mathrm{~L} \mathrm{CH}_{4} \mathrm{~kg}^{-1} \mathrm{VS}\right)$ compared with the initial assays with only G. vermiculophylla. This result confirms the findings of Costa et al. (2012b) during co-digestion of Ulva sp. with sewage sludge. However, the subsequent addition of glycerol ( $2 \%$ and $5 \%$ ) had no significant effect on the methane production, since the BMP varied between 605 and $611 \mathrm{~L} \mathrm{CH}_{4} \mathrm{~kg}^{-1}$ VS (Table 6). In the assay with $10 \%$ glycerol, a severe inhibition occurred probably due to the high concentration of VFA, LCFA and ammonia. The lowest specific methane production ( $277 \pm 5 \mathrm{~L} \mathrm{CH}_{4} \mathrm{~kg}^{-1} \mathrm{VS}$ ) was obtained in this assay.

The results obtained in the present work are significantly higher than the ones found in Costa et al. (2012b), where $294 \mathrm{~L} \mathrm{CH}_{4} \mathrm{~kg}^{-1}$ VS were obtained in the co-digestion of cultivated G. vermiculophylla sample with mixed sludge. As stated in Section 3.2 the differences were caused by the use of an inoculum more active, a higher inoculum to substrate ratio and effective physical pre-treatment, consisting of washing and maceration steps.

\section{Conclusions}

Washing and maceration of $G$. vermiculophylla allow the highest specific methane production $\left(481 \pm 9 \mathrm{~L} \mathrm{CH}_{4} \mathrm{~kg}^{-1} \mathrm{VS}\right)$ due to the removal of impurities and/or potential toxics and increased surface area of the substrate. Thermochemical pre-treatment had no positive effect on methane production, although the substrate solubilisation increased up to $44 \%$. Co-digestion of $G$. vermiculophylla with glycerol or sewage proved to be promising alternatives. Addition of $2 \%$ glycerol increased the methane production to $599 \pm 25 \mathrm{~L} \mathrm{CH}_{4}$ $\mathrm{kg}^{-1} \mathrm{VS}$ ) and co-digestion with sewage sludge caused an increase to $605 \pm 4 \mathrm{~L} \mathrm{CH}_{4} \mathrm{~kg}^{-1} \mathrm{VS}$. 


\section{Acknowledgements}

The authors acknowledge the financial support of the Portuguese Science Foundation (FCT) and European Social Fund (ESF, POPH-QREN) through the grant given to José Carlos Costa (SFRH/ $\mathrm{BDP} / 48962 / 2008$ ), and through the projects: FCOMP-01-0124FEDER-027914 (PTDC/AAG-TEC/3048/2012), financed by FEDER through COMPETE - Programa Operacional Factores de Competitividade; and FCT Strategic Project PEst-OE/EQB/LA0023/2013, the FCT Project RECI/BBB-EBI/0179/2012 and the Project "BioEnv Biotechnology and Bioengineering for a sustainable world", REF. NORTE-07-0124-FEDER-000048, co-funded by the Programa Operacional Regional do Norte (ON.2 - O Novo Norte), QREN, FEDER. We would like to thank Dr. Rui Pereira (Algaplus), for providing the seaweed samples.

\section{References}

Abreu, M.H., Pereira, R., Buschmann, A.H., Sousa-Pinto, I., Yarish, C., 2011. Nitrogen uptake responses of Gracilaria vermiculophylla (Ohmi) Papenfuss under combined and single addition of nitrate and ammonium. J. Exp. Mar. Biol. Ecol. 407, 190-199.

Alvarez, J.A., Otero, L., Lema, J.M., 2010. A methodology for optimising feed composition for anaerobic digestion co-digestion of agro-industrial wastes. Bioresour. Technol. 101, 1153-1158.

Amon, T., Amon, B., Kryvoruchko, V., Bodiroza, V., Pötsch, E., Zollitsch, W., 2006. Optimising methane yield from anaerobic digestion of manure: effects of dairy systems and of glycerine supplementation. Int. Congr. Ser. 1293, 217-220.

Angelidaki, I., Alves, M.M., Bolzonella, D., Borzacconi, L., Campos, L., Guwy, A.J., Kalyuzhnyi, S., Jenicek, P., van Lier, J.B., 2009. Defining the biomethane potential (BMP) of solid organic wastes and energy crops: a proposed protocol for batch assays. Water Sci. Technol. 59, 927-934.

APHA, AWWA, WPCF, 1998. Standard Methods for the Examination of Water and Wastewater, 17th ed. American Public Health Association, Washington, D.C.

Appels, L., Lauwers, J., Degrève, J., Helsen, L., Lievens, B., Willems, K., Van Impe, J., Dewil, R., 2011. Anaerobic digestion in global bioenergy production: potential and research challenges. Renew. Sustain. Energy Rev. 15, 4295-4301.

Bird, K.T., Chynoweth, D.P., Jerger, D.E., 1990. Effects of marine algal proximate composition on methane yields. J. Appl. Phycol. 2, 207-213.

Briand, X., Morand, P., 1997. Anaerobic digestion of Ulva sp. 1. Relationship between Ulva composition and methanisation. J. Appl. Phycol. 9, 511-524.

Bruhn, A., Dahl, J., Nielsen, H.B., Nikolaisen, L., Rasmussen, M.B., Markager, S., Olesen, B., Arias, C., Jensen, P.D., 2011. Bioenergy potential of Ulva lactuca: biomass yield, methane production and combustion. Bioresour. Technol. 102, 2595-2604.

Bruni, E., Jensen, A.P., Angelidaki, I., 2010. Comparative study of mechanical, hydrothermal, chemical and enzymatic treatments of digested biofibers to improve biogas prodution. Bioresour. Technol. 101, 8713-8717.
Costa, J.C., Barbosa, S.G., Alves, M.M., Sousa, D.Z., 2012a. Thermochemical pre- and biological co-treatments to improve hydrolysis and methane production from poultry litter. Bioresour. Technol. 111, 141-147.

Costa, J.C., Gonçalves, P.R., Nobre, A., Alves, M.M., 2012b. Biomethanation potential of macroalgae Ulva spp. and Gracilaria spp. and in co-digestion with waste activated sludge. Bioresour. Technol. 114, 320-326.

Costa, J.C., Sousa, D.Z., Pereira, M.A., Stams, A.J.M., Alves, M.M., 2013. Biomethanation potential of biological and other wastes. In: Gupta, V.K. Tuohy, M.G. (Eds.), Biofuel Technologies. Springer, Heidelberg, Germany, pp. 369-393.

Fountoulakis, M.S., Petousi, I., Manios, T., 2010. Co-digestion of sewage sludge with glycerol to boost biogas production. Waste Manag. 30, 1849-1853.

Hansen, K.H., Angelidaki, I., Ahring, B.K., 1998. Anaerobic digestion of swine manure: inhibition by ammonia. Water Res. 32 (1), 5-12.

Johnson, D.T., Taconi, K.A., 2007. The glycerin glut: options for the value added conversion of crude glycerol resulting from biodiesel production. Environ. Prog. 26, 338-348.

Lourenço, S.O., Barbarion, E., De-paula, J.C., Pereira, L.O.S., Marquez, U.M.L., 2002. Amino acid composition, protein content and calculation of nitrogen-to-protein conversion factors for 19 tropical seaweeds. Phycol. Res. 50, 233-241.

Ma, J., Wambeke, M., Carballa, M., Verstraete, W., 2008. Improvement of the anaerobic treatment of potato processing wastewater in a UASB reactor by codigestion with glycerol. Biotechnol. Lett. 30, 861-867.

Mottet, A., François, E., Latrille, E., Steyer, J.P., Déléris, S., Vedrenne, F., Carrère, H. 2010. Estimating anaerobic biodegradability indicators for waste activated sludge. Chem. Eng. J. 160, 488-496.

Msuya, F.E., Neori, A., 2008. Effect of water aeration and nutrient load level on biomass yield, $\mathrm{N}$ uptake and protein content of the seaweed Ulva lactuca cultured in seawater tanks. J. Appl. Phycol. 20, 1021-1031.

Neves, L., Pereira, M.A., Mota, M., Alves, M.M., 2009. Detection and quantification of long chain fatty acids in liquid and solid samples and its relevance to understand anaerobic digestion of lipids. Bioresour. Technol. 100, 91-96.

NIST/SEMATECH e-Handbook of Statistical Methods, 2012. 5. Process improvement. <http://www.itl.nist.gov/div898/handbook/>.

Nkemka, V.N., Murto, M., 2010. Evaluation of biogas production from seaweed in batch tests and in UASB reactors combined with the removal of heavy metals. J. Environ. Manage. 91, 1573-1579.

Official Methods of Analysis, 2007. Official Method 2003.05, 18th ed. AOAC International, Gaithersburg, MD.

Regueiro, L., Carballa, M. Álvarez, J.A. Lema, J.M., 2012. Enhanced methane production from pig manure anaerobic digestion using fish and biodiesel wastes as co-substrates. Bioresour. Technol. 123, 507-513.

Rosa, P.A.J., Azevedo, A.M., Aires-Barros, M.R., 2007. Application of central composite design to the optimisation of aqueous two-phase extraction of human antibodies. J. Chromatogr. A 1141, 50-60.

Siles, J.A., Martín, M.A., Chica, A.F., Martín, A., 2010. Anaerobic co-digestion of glycerol and wastewater derived from biodiesel manufacturing. Bioresour. Technol. 101, 6315-6321.

Sousa, A.M.M., Alves, V.D., Morais, S., Delerue-Matos, C., Gonçalves, M.P., 2010. Agar extraction from integrated multitrophic aquacultured Gracilaria vermiculophylla: evaluation of a microwave-assisted process using response surface methodology. Bioresour. Technol. 101, 3258-3267.

Villanueva, R.D., Sousa, A.M.M., Gonçalves, M.P., Nilsson, M., Hilliou, L., 2010. Production and properties of agar from the invasive marine alga, Gracilaria vermiculophylla (Gracilariales, Rhodophyta). J. Appl. Phycol. 22, 211-220. 